\title{
Description of the male and larva of Schizomyia tuiuiu Urso- Guimarães \& Amorim (Diptera, Cecidomyiidae), new records and a key to Neotropical species of Schizomyia Kieffer
}

\author{
Maria V. Urso-Guimarães ${ }^{1,2}$ [D
}

\author{
1 Laboratório de Sistemática de Diptera, DBio, CCHB, Universidade Federal de São Carlos - Campus Sorocaba, \\ Rod. João Leme dos Santos, Km 110 - SP-264, Bairro do Itinga, Sorocaba, SP, Brazil, 18052-780 (permanent address) \\ 2 Museu de Zoologia da Universidade de São Paulo/USP (MZSP), Av. Nazaré, 481, Ipiranga, São Paulo, SP, Brazil, $04263-000$ (present address) \\ (mvirginiaurso@gmail.com)
}

\begin{abstract}
Male and larva of Schizomyia tuiuiu Urso-Guimarães \& Amorim, 2002 are described, new occurrences of S. tuiuiu and S. maricaensis Sousa \& Maia, 2007 are registered and a key to Neotropical species of Schizomyia Kieffer, 1889 are presented. The examined specimens are deposited in the Museu de Zoologia da Universidade de São Paulo (MZUSP).
\end{abstract}

KEYWORDS. Asphondyliini, gall midge, geographical distribution, Neotropical region, taxonomy.

RESUMO. Descrição de macho e larva de Schizomyia tuiuiu Urso-Guimarães \& Amorim (Diptera, Cecidomyiidae), novas occorências e uma chave para espécies neotropicais de Schizomyia Kieffer. Macho e larva de Schizomyia tuiuiu Urso-Guimarães \& Amorim, 2002 são descritos, novas ocorrências para S. tuiuiu and S. maricaensis Sousa \& Maia, 2007 são registradas e uma chave para as espécies neotropicais de Schizomyia Kieffer, 1889 (Diptera, Cecidomyiidae) é apresentada. Os espécimes estudados estão depositados no Museu de Zoologia da Universidade de São Paulo (MZUSP).

PALAVRAS-CHAVE. Asphondyliini, distribuição geográfica, galhadores, Região Neotropical, taxonomia.

Schizomyia Kieffer, 1889 is a worldwide genus of Asphondyliini with 70 species associated with more than 30 families of plants (GAGNÉ \& JASCHHOF, 2017; ElSAYED et al., 2018). Ten species of Schizomyia are known from the Neotropical region: S. ipomoeae, Felt 1910 from Guadeloupe; S. stachytarphetae Barnes, 1932 from Trinidad; S. serjaniae Möhn, 1960 and S. loroco Gagné, 2008 from El Salvador; and S. manihoti Tavares, 1925, S. tuiuiu Urso-Guimarães \& Amorim, 2002, S. macrocapillata Maia, 2005, S. spherica Maia \& Oliveira, 2007, S. maricaensis Sousa \& Maia, 2007, and S. santosi Maia \& Araújo, 2009 from Brazil. Two species are associated with Bauhinia spp. from Brazil: Schizomyia tuiuiu, with Bauhinia rufa (Bong.) Steud from Cuiabá, state of Mato Grosso (Urso-GuimarÃEs \& AMORIM, 2002) and $S$. macropillata Maia, 2005, associated with Bauhinia brevipes Vogel from Três Marias, state of Minas Gerais (MaIA \& FERNANDES, 2005), both in hairy leaf galls.

In this paper, the male and larva of Schizomyia tuiuiu are described and illustrated, and the association with
Bauhinia species is discussed. The record of occurrence of $S$. tuiuiu and S. maricaensis in the state of São Paulo, Brazil is registered for the first time. A key to the Neotropical species of Schizomyia is provided.

\section{MATERIAL AND METHODS}

Branches of Bauhinia holophylla (Bong.) Steud. (Fabaceae) with leaf hairy galls were collected in a cerrado vegetation area in Ribeirão Preto, state of São Paulo, Brazil (21 ${ }^{\circ} 22^{\prime} 10.61^{\prime \prime} \mathrm{S}, 48^{\circ} 15^{\prime} 58.99^{\prime \prime} \mathrm{W}, 589 \mathrm{~m}$ a.s.l.) in 21.xi.2001; and branches of an unidentified liana with vein leaf swollen were collected in ciliary forest vegetation area in Ribeirão Preto, state of São Paulo, Brazil (21 07 '28.2”S, $47^{\circ} 39^{\prime} 46.4^{\prime \prime} \mathrm{W}, 527 \mathrm{~m}$ a.s.1.) in 10.i.2002, both by Dr. Olga Kotchetkoff-Henriques. Rearing of adults and slide mounting technics following protocols described by GAGNÉ (1994). The examined specimens are deposited in the Museu de Zoologia of the Universidade de São Paulo, São Paulo, Brazil (MZUSP). 
The characters to the key of identification were taken directly from the specimens of $S$. manihoti, S. serjaniae, S. maricaensis, S. macrocapillata, S. santosi, S. spherica, and $S$. tuiuiu; and from the original description of S. loroco (GAGné \& MENJivar, 2008).

\section{RESULTS AND DISCUSSION}

\section{Schizomyia Kieffer, 1889}

Schizomyia KIEFFER, 1889:183. Type species, Schizomyia galiorum Kieffer, 1889 (by monotipy).

Generic placement and diagnosis. Schizomyia is considered a 'catch-all' genus for species of the supertribe Schizomyiina (GAGNÉ, 1994; GAGNÉ \& JASCHHOF, 2017). Recently, ELSAYED et al. (2018) proposed that Schizomyia can be distinguished from the other genera of Schizomyiina by the following combination of characters: palpi four-segmented and ovipositor protrusible, with needlelike protrusible portion (GAGNÉ, 1994; GaGnÉ \& MenJIVAR, 2008), tarsomeres I without ventroapical extension, except $S$. maricaensis Sousa $\&$ Maia (Sousa \& MAIA, 2007) and S. novoguineensis Kolesik (KOLESIK \&BUTTERILL, 2015), and larva usually with bilobed spatula and eight or fewer terminal papillae. KolesIK \&
BUTTERILL (2015) discussed the variation of the number and shape of papillae in the larval terminal segment among the Schizomyia species, ranging from four setose pairs to a single corniform pair, and the absence or presence of cercilike (dorsobasal) lobes in the ovipositor. Additionally, it was observed that the male gonocoxite of the Neotropical species is oblong instead as almost rectangular in non-Neotropical species of Schizomyia (Fig. 7).

\section{Schizomyia tuiuiu Urso-Guimarães \& Amorim, 2002}

(Figs 1-12)

Schizomyia tuiuiu Urso-GuIMARÃEs \& AMORIM, 2002:568

Description. Male. Wing $2.0 \mathrm{~mm}$ long, $0.4 \mathrm{~mm}$ wide $(\mathrm{N}=2)$. Color: light and dark-banded flagellomeres (Fig. 1) and legs; thorax brown; wing veins covered with dark brown scales and setae, wing membrane hyaline; legs and abdomen covered with dark brown scales and setae, tergites and sternites brown, non-sclerotized areas orange. Head (Fig. 1). Eye holoptic, facets hexagonal, closely adjacent, eye bridge 9 facets long, occiput brown with long hairs; occipital protuberance absent. Antenna with scape rectangular, pedicel rounded, 12 flagellomeres, cylindrical, necks bare; all approximately the same length, light basally and dark

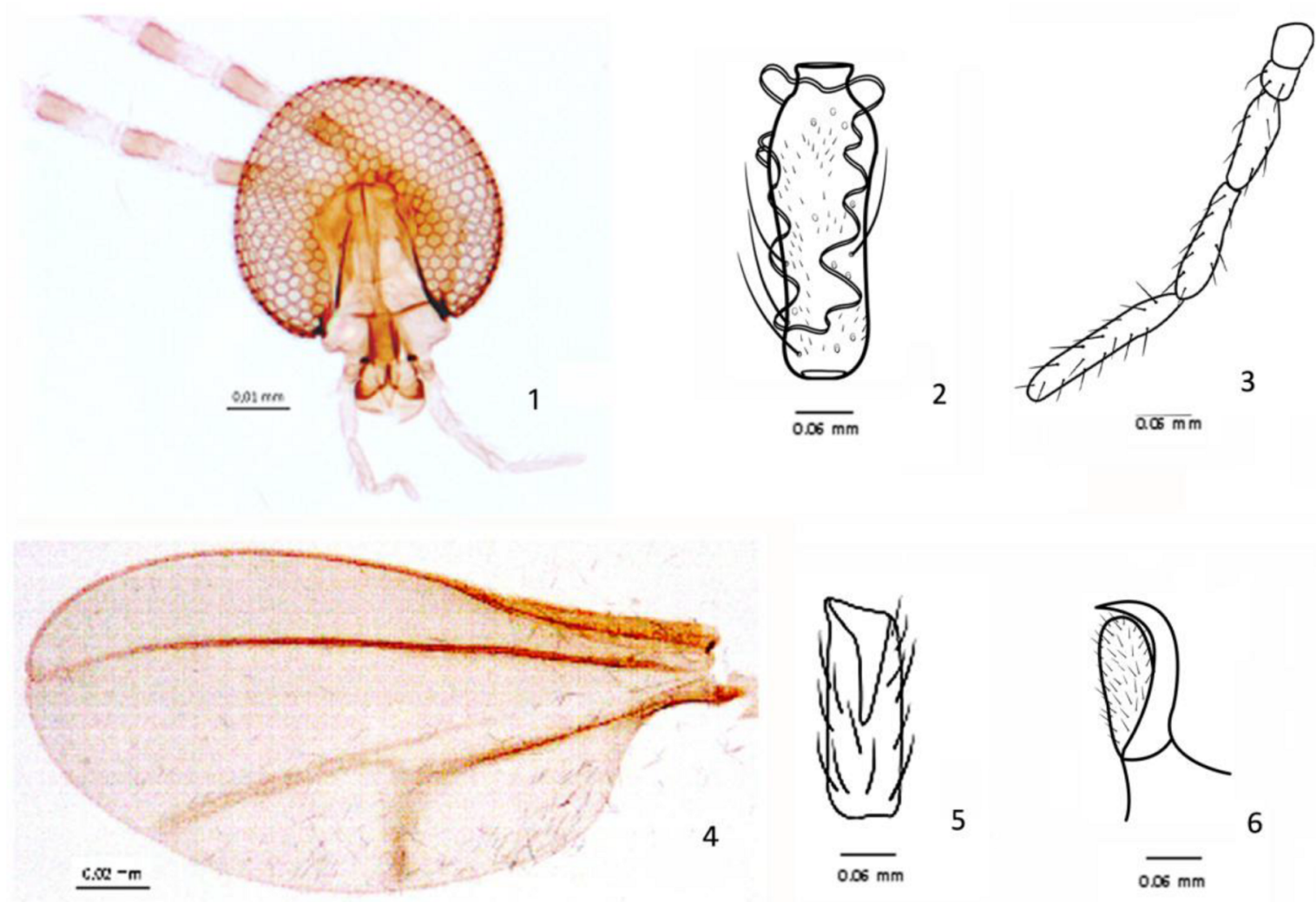

Figs 1-6. Male of Schizomyia tuiuiu Urso-Guimarães \& Amorim, 2002: 1, head (frontal view); 2, third flagelomere; 3, palpus; 4, wing; 5, first tarsomere; 6 , tarsal claw and empodium. 


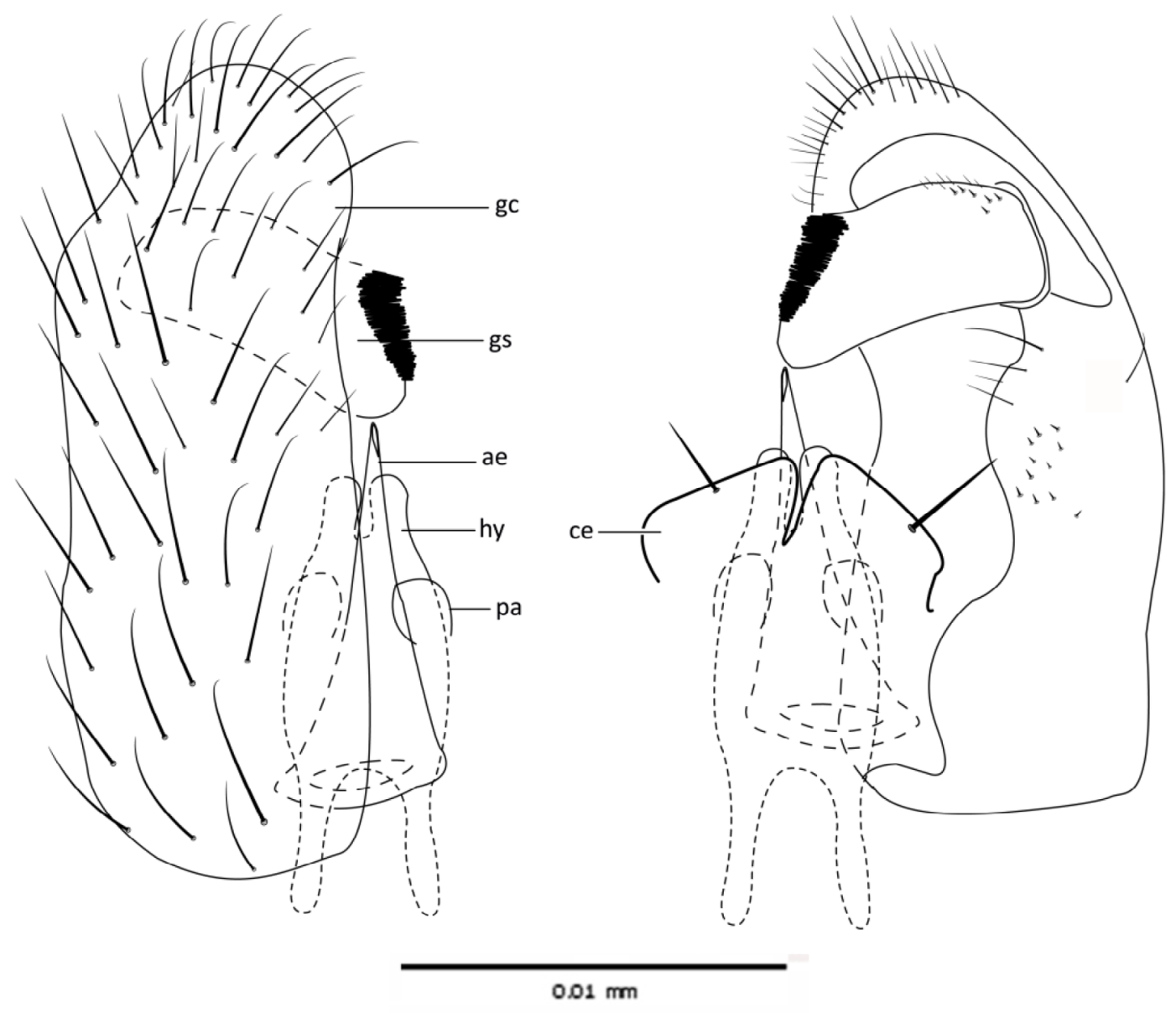

Fig 7. Male of Schizomyia tuiuiu Urso-Guimarães \& Amorim, 2002. Terminalia ventral view , left and dorsal view , right (ae, aedeagus; ce, cercus; gc, gonocoxite; gs, gonostyle; hy, hypoproct; pa, paramere).

distally; circumfila sinuous (Fig. 2). Frontoclypeus with 19 setae; labella hemispherical in frontal view, completely setose distally; palpus 4-segmented, first and second segments equally long, third longer, fourth longest, all cylindrical, setae number and position as in Figure 3.

Thorax. Wing blade hyaline, veins covered with scales and setae (Fig. 4). Antepronotal lobe bare. Scutum and scutelum dark brown, completely fused, scutum with three rows of dorsocentral setae, scutelum with row of macrosetae, anepistern with 40 setae, anepimeron with 19 macrosetae, katepistern and mediotergite bare; laterotergites with two trichoid sensila at halter base. Legs with first tarsomere without apicoventral spur (Fig. 5); tarsal claws without tooth in all legs, bent beyond midway apex, empodia as long as claws (Fig. 6).

Abdomen. Tergites and sternites rectangular except for tergite 8 that is narrow; tergites and sclerites $2-7$ with posterior line of strong setae, completely covered with scales, and a pair of trichoid sensilla anteriorly (except for sternite 2).

Terminalia (Fig. 7). Gonocoxites oblong, completely covered with setae and microsetae, with large ventro-apical lobe exceeding insertion of gonostylus; gonostylus inserted dorsally, gonostylus rectangular with a projection in ventral portion of apex and a dorso-apical row of strong spines partially fused at base in dorsal portion of apex; cerci as long as hypoproct; hypoproct bilobed, narrow, setose, shorter than aedeagus; parameres short, round, setose; aedeagus narrow-triangular, strongly sclerotized, tapering gradually toward apex, round at apex.

Complementary description of pupa (Figs 8,9 ). Color orange. Body $2.5 \mathrm{~mm}$ long $(\mathrm{N}=3)$. Cephalic region with pair of setae; antennal horns absent, upper and lower frontal horns absent, one pair of lower facial papillae with long setae, three pairs of lateral papillae (one setose and two bare); prothoracic spiracle long, setiform. Abdominal tergites 2-7 with field of strong simple spines, concentrated in discal area of tergites; terminal segment with two rounded lobes.

Larva (Figs 10, 11). Color white, body elongate, cylindrical, tapered anteriorly, broadly rounded posteriorly. Integument smooth. Spatula with pair of pointy anterior lobes and long shaft posteriorly. Lateral papillae in two triplets on each side of spatula, each triplet with two setose papillae and 1 asetose papilla. Eighth abdominal segment with a 

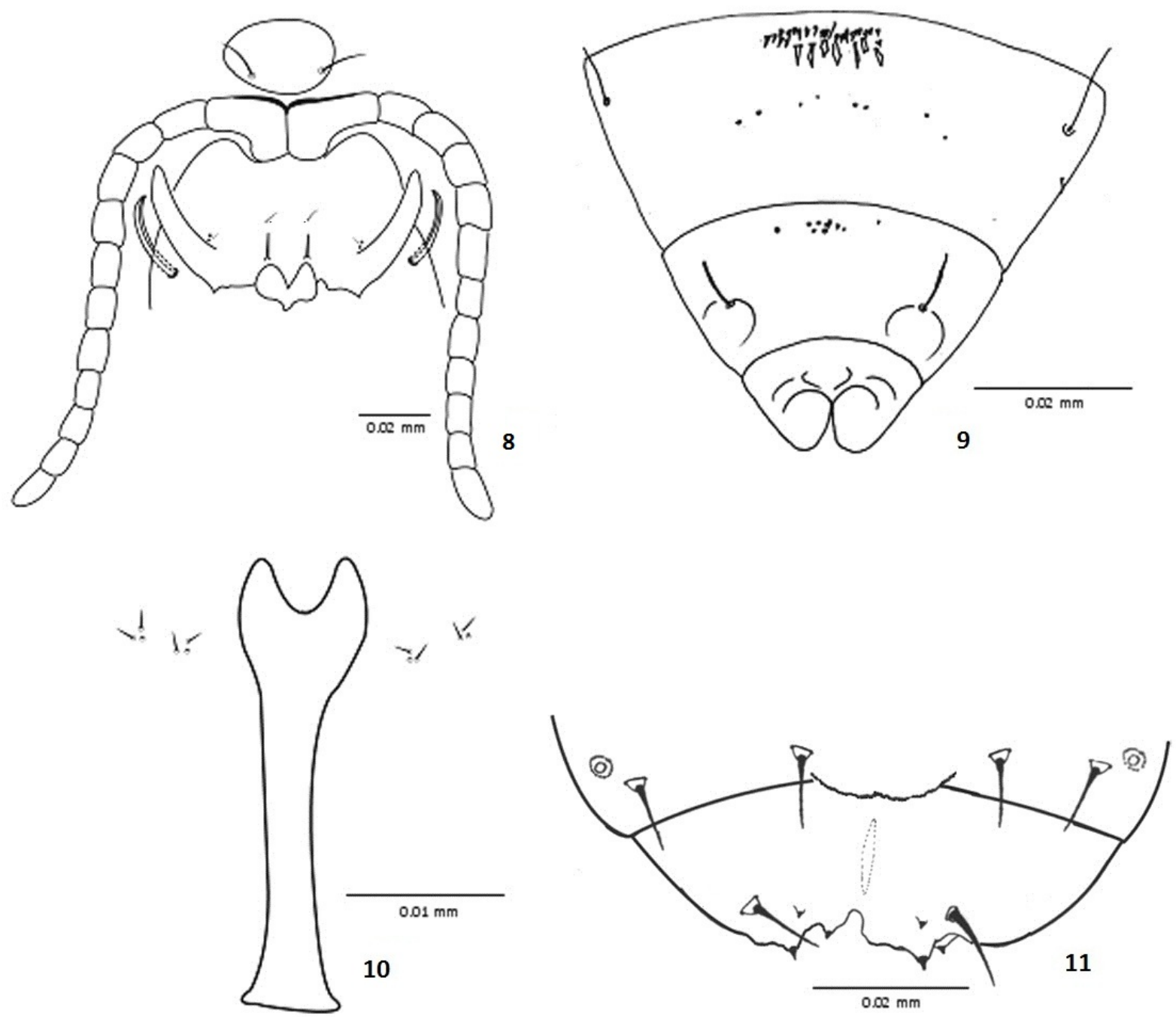

Figs 8-11. Schizomyia tиiuiu Urso-Guimarães \& Amorim, 2002. Figs 8, 9, pupa: 8, cephalic region (ventral view); 9, posterior region (dorsal view); Figs.10, 11, larva: 10, prothoracic spatula and lateral papillae (ventral view); 11, terminal segment (dorsal view).

mediodorsal lobe discrete on posterior margin; terminal segment with four pairs of papillae, three corniform and one with a long setae.

Examined material. 2ð, 2 pupal exuviae, 1 pupa, 1 larva from BRAZIL, São Paulo: Ribeirão Preto $\left(21^{\circ} 22^{\prime} 10.61^{\prime \prime} \mathrm{S}, 48^{\circ} 15^{\prime} 58.99\right.$ 'W), reared from leaf galls of Bauhinia holophylla, collected 21.xi.2001, emerged 25.xi.2001; Dr. Olga Kotchetkoff-Henriques coll. and det.

Gall and biology (Fig.12). Leaf galls in Bauhinia holophylla (Fabaceae): globular, hairy, pale brown to redbrownish, changing the color as the gall matures, unilocular. Pupation occurs in the gall.

New remarks to Schizomyia tuiuiu and comments on host plant. Schizomyia tuiuiu was described based on female and pupae sampled emerged from galls in Bauhinia $r u f a$. The specimens herein described are males, exuviae and larvae emerged from galls in Bauhinia holophylla from Ribeirão Preto, SP. I compared the common structures of adult and pupa specimens and verified that the pupal characters of the two localities do not have morphological divergences, as well as the morphology of the thorax, legs and head (except for antenna, with sexual dimorphism). With the description of the larva, pupal exuvia of male and male of S. tuiuiu, it is possible to point out some differences from the congeneric species by having a discrete mediodorsal lobe on the posterior margin of the larval eighth abdominal segment, two rounded lobes on the terminal segment of the male exuvia, and apical tooth of gonostylus with a row of partially fused strong spines. The original description described the association of S. tuiuiu with Bauhinia rufa (Bong.) Steud. and the new specimens were reared from $B$. holophylla (Bong.) Steud., suggesting a new host plant to $S$. tuiuiu. But, examining the taxonomy of the Bauhinia species (VAz, 2003, 2015), Bauhinia rufa var. cordata (Vogel) Benth. is a heterotypic synonym of Bauhinia holophylla with geographical distribution in Midwest and Southeast Brazil, instead of B. ruffa distributed only in Goiás and Minas Gerais (VAz, 2003). Therefore, from now, the host plant of Schizomyia tuiuiu is Bauhinia holophylla due to the synonymy of these species. 
New record to Schizomyia maricaensis Sousa \& Maia, 2007. Schizomyia maricaensis Sousa \& Maia, 2007 was described from Restinga de Barra de Maricá/ $\mathrm{RJ}$ inducing rosette bud galls in Tetrapterys phlomoides (Malpighiaceae). Herein, I am recording a new locality of geographical distribution to this species, which pupa and female emerged from swollen leaf veins of an unidentified liana with vein leaf swollen were collected in ciliary forest vegetation area in Ribeirão Preto, state of São Paulo, Brazil. The specimens were identified as $S$. maricaensis due to the characters of the female ovipositor (Fig. 13) and the unique terminal segment of pupa, bilobed and sclerotized (Fig. 14). Pupation occurs in the gall.

Examined material. 29,1 pupal exuvia, BRAZIL, São Paulo: Ribeirão Preto $\left(21^{\circ} 07^{\prime} 28.2^{\prime}\right.$ 'S, 47 $39^{\circ} 46.4^{\prime \prime} \mathrm{W}$, $527 \mathrm{~m}$ a.s.1.), gall collected 10.i.2002, emerged 10.i.2002; Dr. Olga Kotchetkoff-Henriques coll.

Key to species of Schizomyia in Neotropical region. Although adult characters are important for identification of genera in Asphondyliini, immature characters are essential for distinguishing species, once adult characters are very similar at the species level. For his reason, from the ten Neotropical species of Schizomyia, two are not included in this key because the larval instar is unknown, and the adult characters are indistinguishable: S. ipomoeae obtained from flower bud galls of Ipomoea sp. (Convolvulaceae) distributed in Guadeloupe FWI and St. Vincent, and S. stachytarphetae, obtained from seeds of Stachytarpheta cayennensis and $S$. jamaicensis (Verbenaceae) in Guadeloupe FWI and Trinidad. Gagné \& Menjivar (2008) divided the Western Hemisphere species of Schizomyia in two groups, the first with hook-like tarsal claws and empodia nearly as long as the claws, including the Neotropical species $S$. ipomoeae, S. macropillata, S. santosi, S. serjaniae, S. stachytarphetae, and $S$. tuiuiu, and the second with falcate tarsal claws and empodia no more than one-third of the claws length, which includes the Neotropical species $S$. loroco, S. manihoti, $S$. spherica, and $S$. maricaensis. Other character shared by the first group of Neotropical species of Schizomyia are the light and dark-banded flagellomeres in Schizomyia loroco, S. impatientis, and S. rivinae, also present in S. macropillata,
S. santosi, S. stachytarphetae, and S. tuiuiu. Other important character to separate species of the genus is the variation in the terminal papillae of the larval terminal segment, ranging from four setose pairs to a single corniform pair (KOLESIK \& ButteriLl, 2015). To the Neotropical species with known larvae, the ranging vary from four pairs of small setiform papillae in S. spherical; three corniform and one setiform very long in S. tuiuiu and S. manihot; and one corniform and three setiform in S. macropillata, S. santosi, S. serjaniae and $S$. loroco. The variation in the larval and some of the adult characters in Neotropical species of Schizomyia allows the construction of a key for these species.

1. Tarsal claws falcate and empodia no more than one-third of the claws length 2 - Tarsal claws hook-like and empodia nearly as long as the

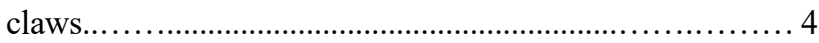

2. Frontoclypeus and anepimeron with more than 40 setae; male tergite 8 not sclerotized; gonocoxites constricted near midlength; gonostylus round with a row of strong spines partially fused at base covering all apex of gonostylus;

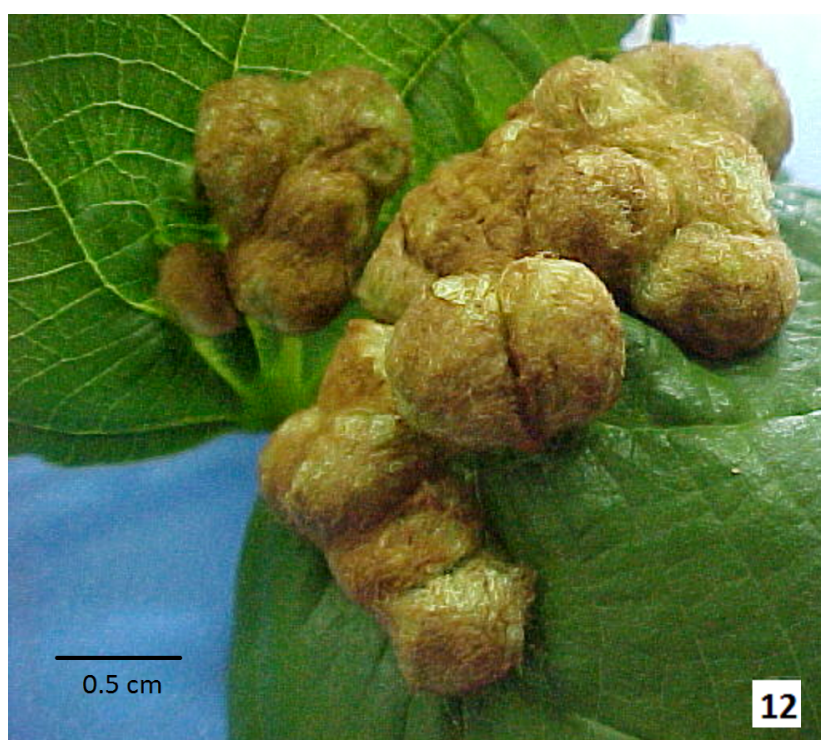

Fig. 12. Galls of Schizomyia tuiuiu Urso-Guimarães \& Amorim, 2002 induced in leaves of Bauhinia holophylla (Bong.) Steud. (Fabaceae).

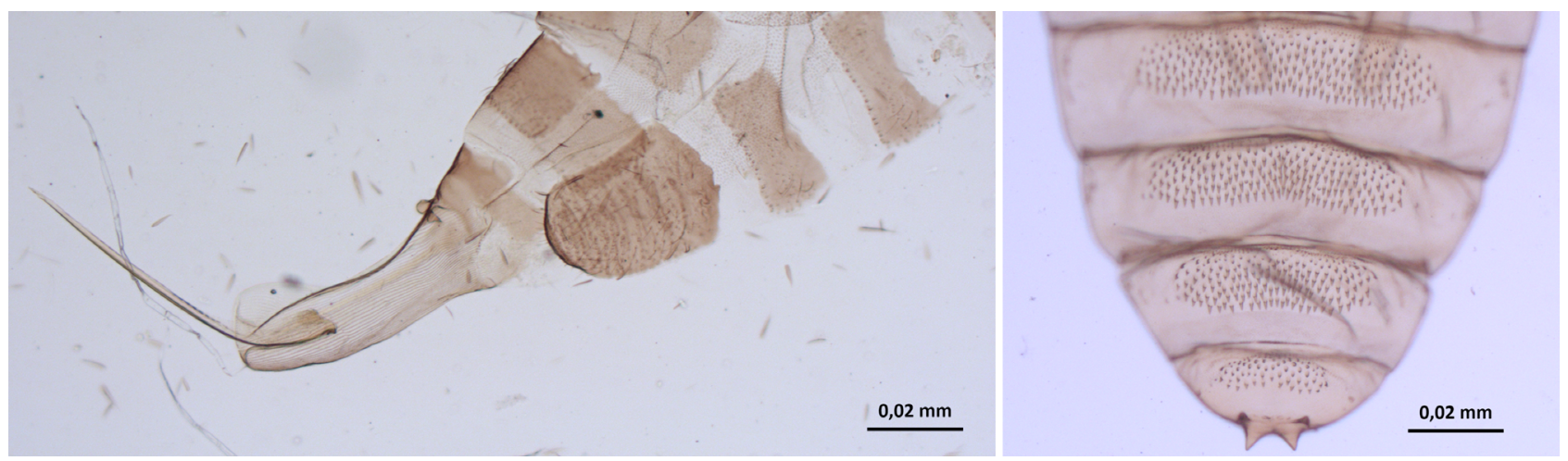

Figs 13, 14. Schizomyia maricaensis Sousa \& Maia, 2007: 13, ovipositor (ventro-lateral view, left); 14, terminal segment bilobed and sclerotized of pupa (dorsal view, right). 
abdominal segments of pupa with numerous transverse rows of dorsal spines at discal region; induce rosette bud galls in Tetrapterys phlomoides (Spreng.) Nied. (Malpighiaceae) (Brazil: Rio de Janeiro, Restinga de Barra de Maricá; São Paulo: Ribeirão Preto) ............. S. maricaensis Sousa \& Maia - Frontoclypeus and anepimeron with less than 40 setae; gonocoxites not constricted near midlength; gonostylus rectangular with a projection in ventral portion of apex and a dorso-apical row of strong spines partially fused at base in apex; abdominal segments of pupa with few dorsal spines (not in rows) only in the discal region; induce galls in other host plants ....3 3. Terminal papillae: three setiform and one corniform; light and dark-banded flagellomeres; male cerci round and divided in base; male hypoproct deeply bilobed; larva in deformed flower buds of Fernaldia pandurata (A. DC.) Woodson (Apocynaceae) (El Salvador: Nueva Concepcion, Chalatenango; Guatemala to Costa Rica)

S. loroco Gagné

- Terminal papillae: one setiform and three corniform; flagellomeres not light and dark-banded; male cerci round and fused in base; male hypoproct shallowly bilobed; larva in globular, rugose leaf galls in Manihot utilissima (Euphorbiaceae) (Brazil: Ceará; Colombia)

S. manihoti Tavares

4. Larva with four pairs of terminal papillae, three setiform and one corniform

- Larva with four pairs of terminal papillae in other combination ....................................................... 7 5. Ovipositor smaller than abdomen, at most 4.5 times longer than $7^{\text {th }}$ sternite; larva in closed, swollen, and deformed galls in flowers of Serjania goniocarpa (Sapindaceae) (El Salvador: San Salvador) ................... S. serjaniae (Möhn) - Ovipositor longer than abdomen, at least 5.5 times longer than $7^{\text {th }}$ sternite; larva in other host plants

6. Female without cercilike lobes; male hypoproct deeply bilobed; larva in flower buds of Jacquemontia holosericea (Weinman) O’Donnel (Convolvulaceae) (Brazil: Rio de Janeiro, Restinga de Barra de Maricá) ....

S. santosi Maia \& Araújo - Female with cercilike lobes; male hypoproct shallowly bilobed; larva in hairy leaf galls in Bauhinia brevipes (Fabaceae) (Brazil: Minas Gerais, Três Marias) ...................................... S. macropillata Maia 7. Larval terminal papillae: four short setiform papillae; mediodorsal of lobe on the posterior margin of the larval eighth abdominal segment absent; larva in spherical galls in lateral and apical bud galls in Sebastiania glandulosa (Mart.) Pax. (Euphorbiaceae) (Brazil: Rio de Janeiro, Restinga de Barra de Maricá) ................... S. spherica Maia \& Oliveira - Larval terminal papillae: one setiform and three corniform; mediodorsal lobe on the posterior margin of the larval eighth abdominal segment present; larva in hairy leaf galls in Bauhinia holophylla (Bong.) Steud. (Fabaceae) (Brazil: Mato Grosso: Cuiabá; São Paulo: Ribeirão Preto)

\section{S. tuiuiu Urso-Guimarães \& Amorim}

Acknowledgements. The author acknowledges the support from FAPESP Proc. \#99/01429-1; Dr. Carlos J.E. Lamas for providing access to the facilities in MZUSP, Dr. Olga Kotchekoff-Henriques (SMMA/ PMRP) for collecting the branches with galls and for identifying the host plant species; and comments of three anonymous reviewers in the manuscript during the peer review process.

\section{REFERENCES}

Elsayed, A. K.; Yukawa, J. \& ToKuda, M. 2018. A taxonomic revision and molecular phylogeny of the eastern Palearctic species of the genera Schizomyia Kieffer and Asteralobia Kovalev (Diptera, Cecidomyiidae, Asphondyliini), with descriptions of five new species of Schizomyia from Japan. ZooKeys 808:123-160. https://doi.org/10.3897/ zookeys.808.29679

Gagné, R. J. 1994. The Gall Midges of the Neotropical Region. Ithaca, Cornell University Press. xiv $+352 p$.

Gagné, R. J. \& Jaschhof, M. 2017. A Catalog of the Cecidomyiidae (Diptera) of the World. 4ed. Digital. 762p. Available at $<$ https://www. ars.usda.gov/ARSUserFiles/80420580/Gagne_2017_World_Cat_4th_ ed.pdf $>$. Accessed on 02 July 2018.

Gagné, R. J. \& MenjIVAR, R. 2008. A new species of Schizomyia (Diptera: Cecidomyiidae), a pest of Fernaldia pandurata (Apocynaceae) in Central America. Proceedings of the Entomological Society of Washington 110:384-291.

Kieffer, J.-J. 1889. Neue Beiträge zur Kenntniss der Gallmücken. Entomologische Nachrichten 15:183-194.

Kolesik, P. \& Butterill, P. T. 2015. New gall midges (Diptera: Cecidomyiidae) from Papua New Guinea. Austral Entomology 54:79-86.

Maia, V. C. \& Fernandes, G. W. 2005. Two new species of Asphondyliini (Diptera: Cecidomyiidae) associated with Bauhinea brevipes (Fabaceae). Zootaxa 1091:27-40.

ToKudA, M.; Harris, K. M. \& YuKawA, J. 2005. Morphological features and molecular phylogeny of Placochela Rübsaamen (Diptera: Cecidomyiidae) with implications for taxonomy and host specificity. Entomological Science 8:419-427

Urso-Guimarães, M. V. \& Amorim, D. S. 2002. New Brazilian species of Asphondyliini (Diptera, Cecidomyiidae). Revista Brasileira de Entomologia 46:561-570.

VAZ, A. M. DA F. 2003. Leguminosae - Caesalpinioideae - Cercideae: Bauhinia. In: Rızzo, J. A. coord. Flora dos Estados de Goiás e Tocantins. v.30. 121p.

VAZ, A. M. S. F. 2015. Bauhinia in Lista de Espécies da Flora do Brasil. Jardim Botânico do Rio de Janeiro. Available in: < http://floradobrasil. jbrj.gov.br/jabot/floradobrasil/FB111840>. Accessed on 20 February 2019. 